\section{Ny kunnskap om diastolisk hjertesvikt}

\author{
Norske forskere har oppdaget og kartlagt nye mekanismer for venstre \\ ventrikkels diastoliske funksjon.
}

Halvparten av alle hjertesviktpasienter har redusert systolisk venstre ventrikkel-funksjon, den andre halvparten har diastolisk hjertesvikt. Ekkokardiografi er et viktig diagnostisk verktøy hos pasienter med hjertesvikt. Ved hjelp av nyere ekkokardiografiske teknikker kan myokardbevegelsen i form av deformasjon og hastighet måles direkte. Den tidligdiastoliske mitralringshastigheten (e') brukes over hele verden som en ekkokardiografisk markør på diastolisk hjertefunksjon. Hovedgrunnen til dette er at e' er bestemt av venstre ventrikkels relaksasjonshastighet, en av determinantene til diastolisk funksjon. Redusert tidligdiastolisk fylling av venstre ventrikkel er en viktig manifestasjon av diastolisk dysfunksjon. Mekanismene for e' er imidlertid kun delvis klarlagt. Norske forskere har nå undersøkt om gjenopprettende krefter generert i løpet av systolen (restoring forces) samt tidligdiastolisk load (lengthening load) ville bidra til å bestemme e', i tillegg til relaksasjonshastigheten (1).

- Resultatene viste at størrelsen på de gjenopprettende kreftene er en uavhengig determinant for e', i tillegg til relaksasjonshastigheten. Ingen av disse determinantene kan imidlertid forklare de store endringene i e' som vi observerte ved variasjon av preload. Derimot viser studien at tidligdiastolisk load, som kan forklare disse endringene av e', er en viktig og uavhengig determinant for e', sier førsteforfatter Anders Opdahl ved Institutt for kirurgisk forskning, Oslo universitetssykehus, Rikshospitalet.

- Klinisk sett vil tidligdiastolisk load være relativt lik venstre ventrikkels endediastoliske trykk, og e' bør derfor vurderes i sammenheng med fyllingsgraden. Dessuten vil graden av gjenopprettende krefter

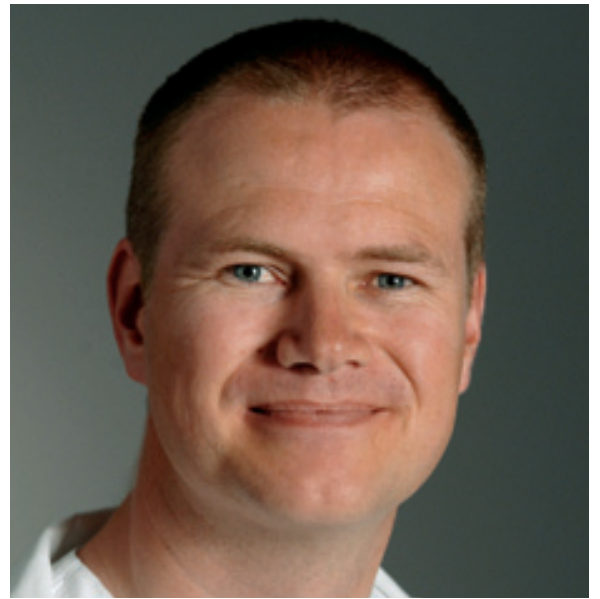

Anders Opdahl, artikkelens førsteforfatter. Foto Bente Devik, Oslo universitetssykehus, Rikshospitalet

være gjenspeilet i endesystolisk lengde samt i størrelsen på kontraksjonen, og e' bør derfor også vurderes i sammenheng med systolisk hjertefunksjon. I det normale hjertet, med rask relaksasjon, vil nok tidligdiastolisk load og gjenopprettende krefter være hovedfaktorene som bestemmer e'. Faktorenes innbyrdes bidrag til e' vil trolig også avhenge av hjertets funksjonelle status, med et større bidrag fra relaksasjonen ved hjertesvikt, sier Opdahl.

\section{Erlend Hem}

erlend.hem@medisin.uio.no

Tidsskriftet

\section{Litteratur}

Opdahl A, Remme EW, Helle-Valle T et al. Determinants of left ventricular early-diastolic lengthening velocity: independent contributions from left ventricular relaxation, restoring forces, and lengthening load. Circulation 2009; 119: 2578-86.

\section{Ordforklaringer}

e': Tidligdiastolisk mitralringshastighet. Reflekterer hastigheten på forlengelsen av venstre ventrikkel.

Relaksasjonshastighet: Måles som tidskonstanten $(\tau)$ for vestre ventrikkels isovolumetriske trykkfall. Reflekterer hastigheten på reduksjonen av aktive kontraktile krefter.

Gjenopprettende krefter: «Restoring forces», elastiske krefter som genereres under kontraksjonen og som gjenoppretter myokards hvilekonfigurasjon når aktive kontraktile krefter avtar.

Tidligdiastolisk load: «Lengthening load», den eksterne ekspanderende kraft under tidlig fyllingsfase.
Er du i ferd med å publisere eller har du nylig publisert i et internasjonalt tidsskrift? Send tips til erlend.hem@medisin.uio.no

\title{
Kardiologisk translasjonsforskning
}

\section{Artikkelen er skrevet av åtte norske forskere.}

Anders Opdahl er lege, ph.d.-student og en del av Otto A. Smiseths forskningsgruppe ved Institutt for kirurgisk forskning og Hjertemedisinsk avdeling, Oslo universitetssykehus, Rikshospitalet. Andreforfatter Espen W. Remme er sivilingeniør og har doktorgrad innen hjertemekanikk/simulering. Hans deltakelse viser betydningen av flerfaglig samarbeid i denne type forskning. Anders Opdahl starter sommeren 2009 som postdoktorstipendiat ved Johns Hopkins
University, der han skal arbeide videre med funksjonell bildefremstilling, bl.a. hos pasienter med diastolisk dysfunksjon.

Smiseths forskningsgruppe arbeider særlig med translasjonsforskning innen kardiovaskulær funksjon, bildefremstilling og biomekanikk. Institutt for kirurgisk forskning ledes av Ansgar O. Aasen. Der får mange kliniske forskere mulighet til å drive translasjonsforskning.
Artikkelen ble publisert 19.5. 2009 i Circulation, som er det høyest rangerte tidsskriftet innen kardiologi 